\begin{tabular}{|l|l|l|l|}
\hline & & $40-46$ & Hannover 2003 \\
\hline
\end{tabular}

\title{
A wild horse (Equus przewalskii Poliakov 1881) of Mesolithic age from Kempen (Germany, Northrhine-Westfalia, Lippe County)
}

\author{
RAINER SPRINGHORN*)
}

SPRINGHORN, R. (2003): A wild horse (Equus przewalskii POLIAKOV 1881) of Mesolithic age from Kempen (Germany, Northrhine-Westfalia, Lippe County). - Eiszeitalter und Gegenwart, 52: 40-46; Hannover.

Keywords: European wild horse, Mesolithic, anatomy, individual age, systematics

Abstract: New skeletal remains of one specimen of the wild horse Equus przewalskii Polıakov 1881 from Kempen (City Horn-Bad Meinberg, East-Westfalia, Germany) are presented. Its sedimentary deposition immediately near Mesolithic artefacts suggests an appropriate age of 10,000-7,000 BP. The grade of teeth abrasion reveals an individual minimum age of 19 years. A prominent lower canine proves male sex. A fourth molar in both lower jaws documents an unusual tooth aberration, and is explained as a genetic aberration. In comparison with already documented horse skeletons of historical times from other localities of eastern Westfalia lower premolars, and first lower molar are distinctly (4$10 \%)$ longer and wider. Consequently, also the total chewing surface is larger. This is important, because the measurements of limb bones show a height of withers $(129-142 \mathrm{~cm})$ of "small shaped" to "middle shaped" (VITT 1952) for both, the Mesolithic horse from Kempen, and the horses from other eastern Westfalian sites of historical times.

[Ein Wildpferd (Equus przewalskii PolıaKov 1881) aus dem Mesolithikum von Kempen (Deutschland, Nordrhein-Westfalen, Kreis Lippe)]

Kurzfassung: Es wird neues Skelettmaterial eines Wildpferd-Individuums Equus przewalskii Poliakov 1881 aus Kempen (Stadt Horn-Bad Meinberg, Ostwestfalen, Deutschland) vorgestellt. Seine Lage im Sediment unmittelbar neben Flintabschlägen der Mittelsteinzeit legen ein entsprechendes Alter von 10.000-7.000 Jahren

\footnotetext{
*) Anschrift des Verfassers: Prof. Dr. Dipl.-Geol. RaineR SPRINGHORN, Lippisches Landesmuseum Detmold, Ameide 4, D-32756 Detmold, Germany. E-mail: Springhorn@lippisches-landesmuseum.de
}

vor der Gegenwart nahe. Der Abkauungsgrad der Zähne ergibt ein Individualalter von wenigstens 19 Jahren. Ein kräftiger unterer Caninus beweist, dass es sich um einen Hengst handelt. Die Existenz eines vierten Molaren in beiden Unterkieferhälften ist außergewöhnlich und wird als genetisch bedingte Abnormität gewertet. Im Vergleich mit bereits publizierten Pferden aus historischer Zeit von anderen ostwestfälischen Fundorten sind die unteren Prämolaren und ersten unteren Molaren deutlich länger und breiter (4-10\%). Analog hierzu ist die Kaufläche insgesamt größer. Dies ist deshalb bedeutsam, weil die Maße der Extremitätenknochen eine Widerristhöhe von 129-142 cm ergeben, die den Kategorien „kleinwüchsig“ bis „mittelwüchsig“ (VITT 1952) entsprechen, die sowohl dem mittelsteinzeitlichen Kempener Pferd als auch den Pferden historischen Alters anderer Lokalitäten in Ostwestfalen zugeordnet werden können.

\section{Introduction}

In October 1989 near the village Kempen in the eastern Westfalian county Lippe, during an excavation for a filter bed skeleton remains of the wild horse (Equus przewalskii) were found. They had been deposited in a Postglacial earthy marl of a former pool, collecting water of three creeks which had been running into the little river Durbeke.

The little archaeological site is situated in the northern part of the Egge Range.

The bones lay in a depth of $1.80 \mathrm{~m}$ below surface niveau. Beside the horse bones, regarding other species, one right metatarsal of a roe-deer (Capreolus capreolus) has been identified. Directly at the basis of the bones, in an undisturbed sedimentary context, was some flint waste flake of Mesolithic age (Luley 1990: 24-25). The finder was Johannes GLiTz (Campingplatz Eggewald, 32805 Horn-Bad Meinberg, Ortsteil Kempen). - The well preserved lower jaws show significant teeth aberration which is worthy to be documented. Complete limb bones allowed the calculation of withers height, and a comparison with known historical horses. 


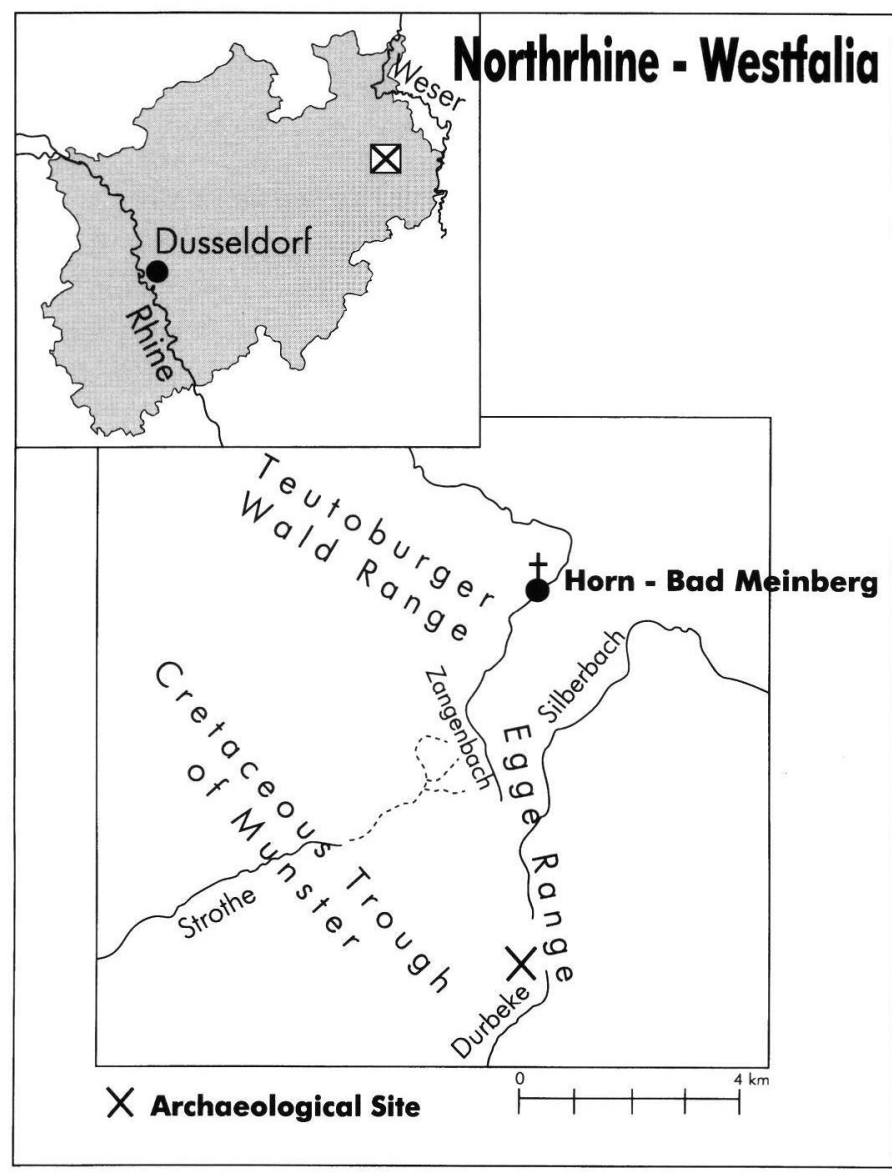

Fig. 1: Map with the archaeological site in the northern Egge Range.

there have been found no Mesolithic sites of Preboreal age $(10,-9,000$ BP) with preserved horse bone material. In this area Equus przewalskii seems to have a rather brief occurrence, "beeing confined to the open birch-pine period of the Preboreal, but with an interesting later re-immigration of Equus in the transition between Atlanticum and Subboreal" (AARIS-SøRENSEN 1992: 148).

\section{Material and Methods}

The here described new horse material is housed in the Lippisches Landesmuseum Detmold, Department „Bodendenkmalpflege" (DKZ No. 4119, 122; U-No. 1581). Measurements were made to the nearest $0.1 \mathrm{~mm}$ by an anthropological orifice plate, and a caliper square INOX from the firm MAUSER. Calculations of withers height base upon the works of KiesEWALTER (1888), VITT (1952), and especially the critical revision of v. D. DRIESCH \& BOESNECK (1974). Anatomical nomenclature for dentition and skeleton was adopted from AlBERDI (1989), NiCKEL, SChummer \& Seiferle (1977), and Siegfried (1983). Individual age determination criteria by incisor abrasion were used in the sense of BRÖM-

Up to now only two horse skeleton complexes from eastern Westfalia with ascertained ages are published (SPRINGHORn 1980 and 1991). Both are of historical age. Moreover, the region between Rhine and Weser is absolutely lacking in Mesolithic and early Neolithic horse material (DöHLE 1999: 152). The assumed Mesolithic age (10,000 - 7,000 BP) of the material presented in this paper stresses its importance.

Meanwhile, the existence of Equus przewalskii during the early Holocene of Northwest Europe is proved by the well known Mesolithic in the Lower and Central Rhineland. Mesolithic sites after 10.000 BP of stone tool assemblages revealed horse remains and indicate "that the Preboreal forest cover was by no means closed" (Street \& BaAles 1999: 29). Farther to the North, in South Scandinavia,
LER (1954). The photographic documentation of bones and teeth were made by a digital camera NIKON C990.

According to the current literature (cf. Volf 1972, Siegfried 1983, Nilson 1983, StarCK 1995, and others) for the wild horse the species name Equus przewalskii POLIAKOv 1881 is used, although CorBET (1978: 94), AARIS-SøRENSEN (1992: 147), and Clutton-Brock \& Burleigh (1991) applied the older synonym Equus ferus BODdAert 1785.

The excavation of Kempen provided several skeleton elements of one individual: Also a few small fragments of the upper skull, three isolated incisors $\left(\mathrm{I}_{3} \sin ., \mathrm{I}^{2-3} \sin\right.$.), a right first upper premolar $\left(\mathrm{P}^{2}\right)$, symphyseal connected lower jaws with left canine and complete cheek tooth rows, pectoral vertebras 
9-12, fragments of another pectoral vertebra, the last presacral vertebra, sacrum, fragmentary left pelvis with ischium and acetabulum, fragments of six ribs, fragmentary right shoulder-blade, right radius with distal part of ulna, left tibia, left metatarsal, and left hind phalanx I.

\section{Description of upper dentition}

Only fragmentary disarticulated premaxillas, and negligible remnants of the palate and maxillas imply existence of only a few isolated teeth of the upper dentition.

The two documented upper incisors ( $\mathrm{I}^{2-3} \sin$.) show subtriangular outlines; that of the $\mathrm{I}^{3}$ is sidebackwards extended. Tooth crowns are deeply chewed off. On the chewing surfaces tracks of the enamel core, so called „yellow star", can distinctly be seen. Due to this amount of abrasion an individual age of at least nineteen years is concluded. The angle of 43 degrees formed by the plane of abrasion and the direction of tooth crown and tooth root of incisors suggest also an age of at least more than fourteen years. The first right upper premolar $\left(\mathrm{P}^{2}\right)$ is also strongly chewed down; consequently its crown is now very low. The areas of fossa anterior and fossa posterior are nearly fused to a narrow ridge. The back contact usur to $\mathrm{P}^{3}$ is extreme and caused loss of the metalophus.

\section{Description of lower jaws}

The incisors bearing frontal region of the muzzle is completely broken up to the canines, but an isolated $\mathrm{I}_{3}$ sin. is documented. Its subtriangular contour is extended sidebackwards, too. The left mandible shows a strong canine, the right one is only represented by its alveole. A wide diastema separates the canine from cheek teeth. Instead of six there are seven cheek teeth. This abnormal phenomenon is documented on both sides of the mandible. The cheek teeth of the left mandible show a stronger abrasion than those of the right one. Both tooth rows document an increasing grade of abrasion backwards posteriorly. The supernumerary seventh cheek teeth have deeply grinded off trigonids, and hypoconids. The moderate abrasion of entoconid and talonid of both last molars is possibly referred to the lack of an antagonist on the upper jaws, might, however, be traced back also to the sloping position in the basal part of the ramus ascendens.
Tracks of chewing on tooth surfaces are strictly transverse. Mainly the surfaces of $\mathrm{P}_{4}-\mathrm{M}_{3}$ are extremely furrowed.

On the right mandible there is a zig-zag crack laterally running down from the irregular molar to the ventral margin of the jaw bone, caused probably by drying after excavation. The medial wall of the ramus ascendens is lightly damaged, the medial part of the processus glenoidalis broken. The left mandible had only been damaged at the uppermost top of processus coronoideus.

\section{Results and Discussion}

The modern horse Equus przewalskii Poliakov 1881 made its appearance known in Europe in 4Würm II stadial (KURTEN 1968: 150). According to WieganK (1983: 358) and NiLSON (1983: 478) Equus przewalskii already is beside Equus germanicus the relevant horse of the early Weichsel Glacial (4Würm I stadial sensu KurTen). However, I agree with STARCK (1995: 971) that, despite of a gradual decrease in size of the wild horse since the Middle Pleistocene (Forsten 1993, KoEnigswald et al. 1995), there is hardly no real morphological difference to specialize distinct species. That is why I do not see any evidence to establish neither a valid more robust species Equus germanicus NeHRING 1884 nor a medium sized Upper Pleistocene horse Equus remagensis (NEHRING 1884) (cf. NOBIS 1971: 46). The species E. przewalskii had been common in the postglacial. The skeleton material presented here is presumably of Mesolithic age. Robustness of the left lower canine proves male sex of the specimen. Corresponding by the amount of incisors abrasion an individual age of at least nineteen years is supposed. This is supported by the narrow angle between their abrasion surfaces relative to directions of tooth crowns and roots. Enamel faulting and tooth structure confirm three premolars $\left(\mathrm{P}_{2-4}\right)$ and three molars $\left(\mathrm{M}_{1-3}\right)$ as normal elements of lower jaw dentition. The irregular seventh tooth exhibits the same pattern as $\mathrm{M}_{3}$, but is anteroposteriorly weakly compressed. According to its position in the jaw bone there must have been a lengthening of the molareous morphogenetical compartment during embryonic ontogeny. Subsequently there was a tooth germ installation of a fourth lower molar. In comparison with the early Mesolithic horse 


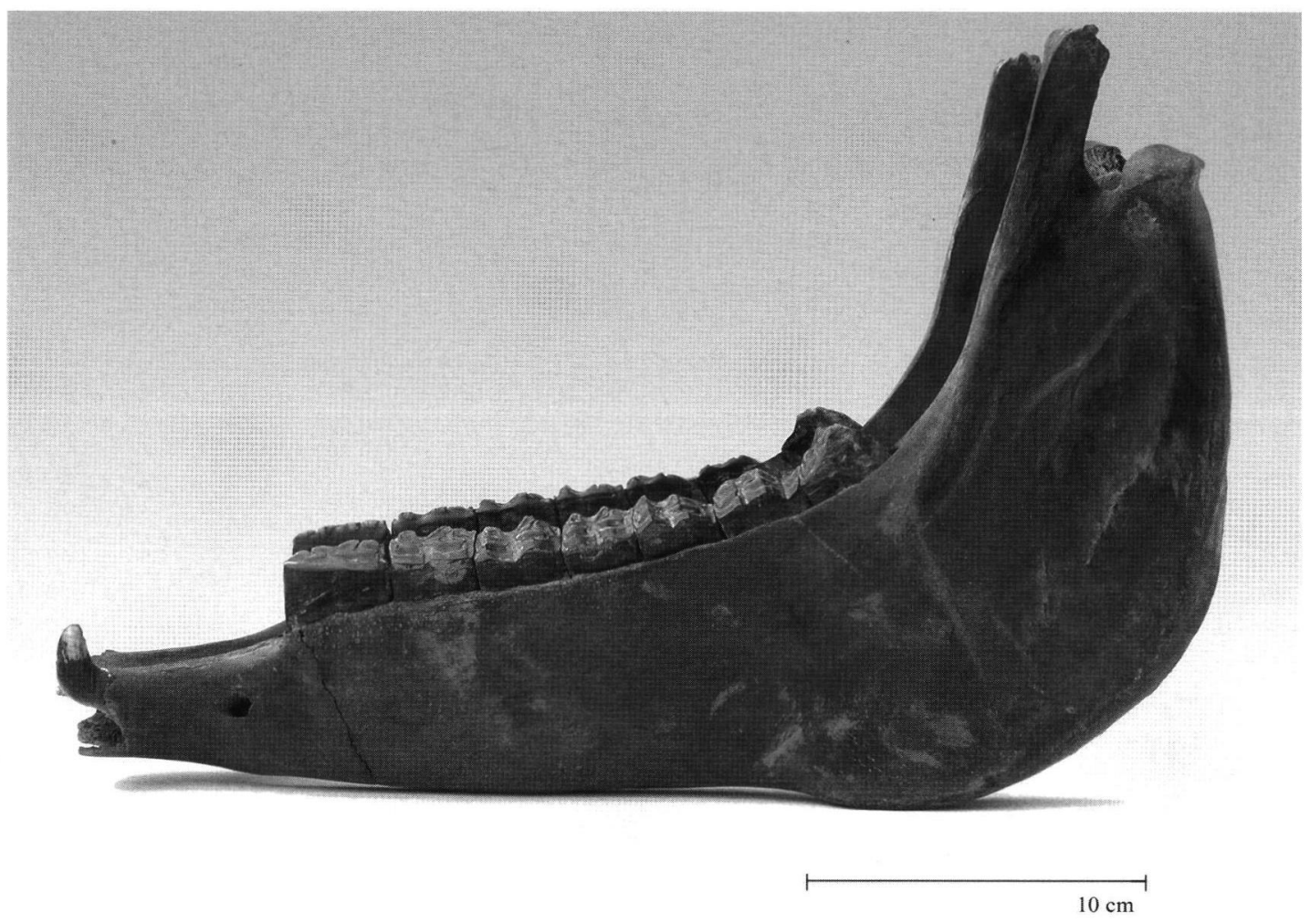

Fig. 2a: Lower jaw of Equus przewalskii from Kempen; lateral view of left mandible.

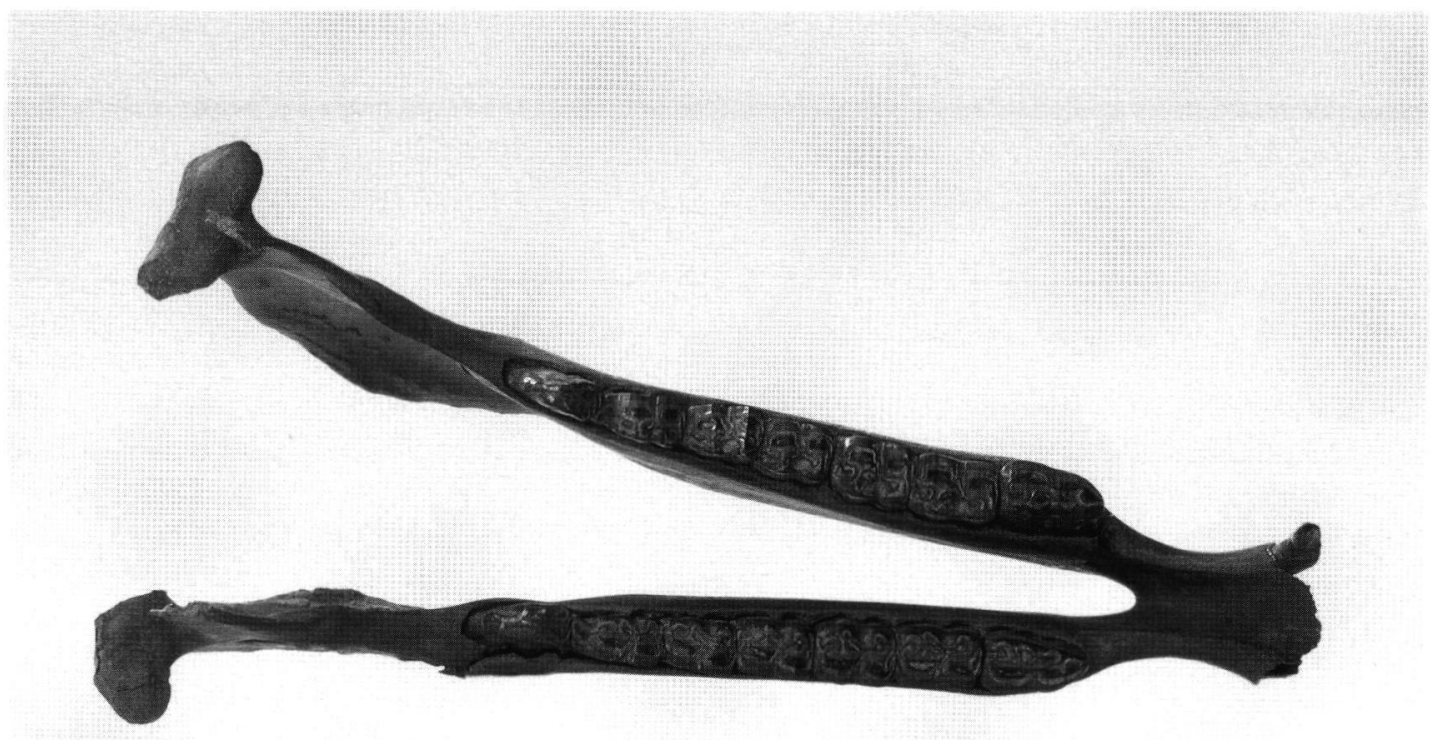

Fig. 2b: Lower jaw of Equus przewalskii from Kempen; occlusal view. 


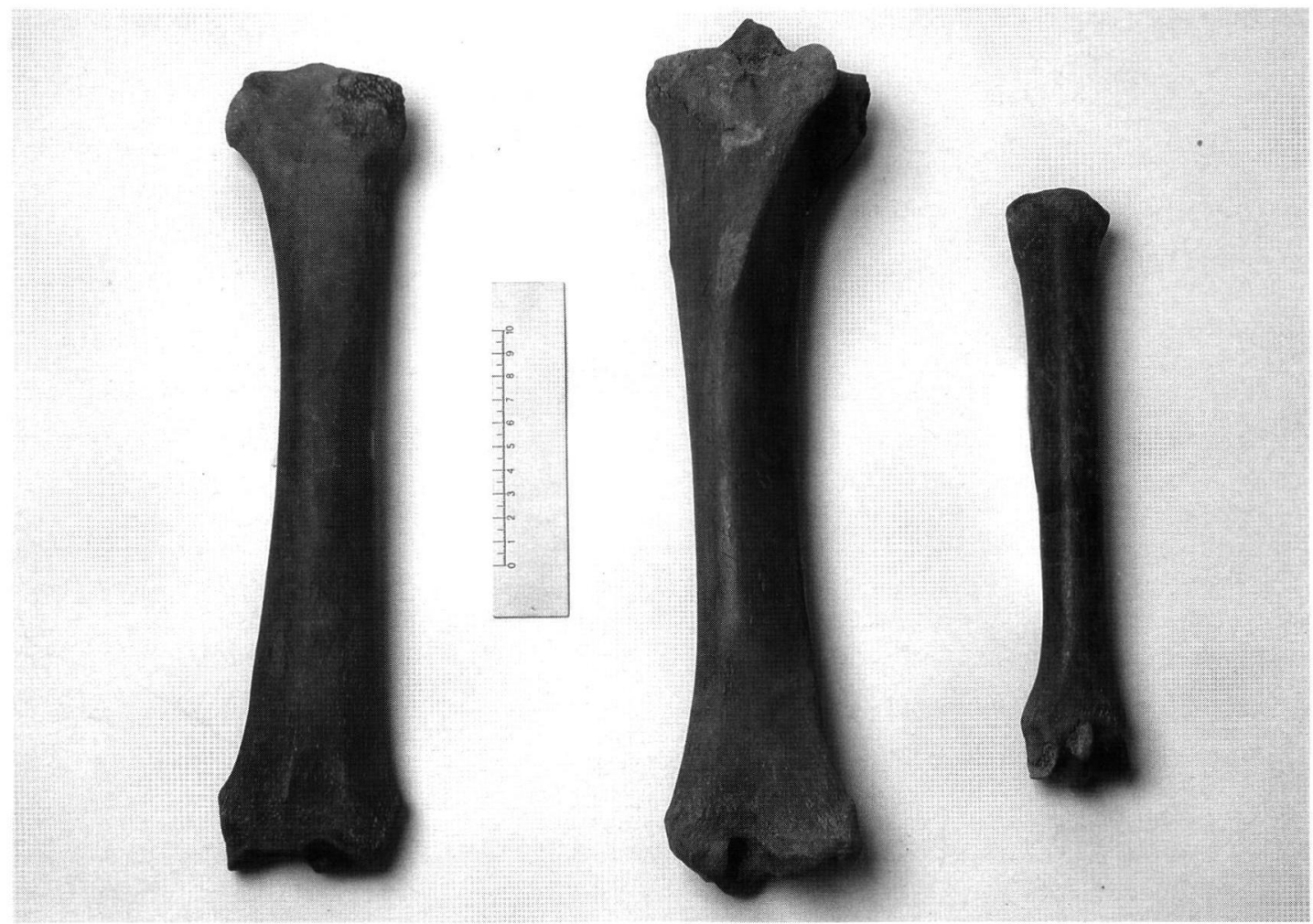

Fig. 3: Limb bones of Equus przewalskii from Kempen; from left to right: Radius dext., tibia sin., and metatarsale sin.

mandible from Seamer Carr (Yorkshire, England) the measurements $\mathrm{P}_{2}-\mathrm{M}_{3}$ exhibit moderate differences (Clutton-Brock \& Burleigh 1991: 240). The premolars throughout are somewhat shorter, but on the contrary, the molars are of equal length $\left(\mathrm{M}_{1}\right)$ or slightly longer. All cheek teeth are significantly wider with exception of $\mathrm{P}_{3}$ showing equal width.

The lower jaw teeth of the horse from Kempen, regarding premolars and first molar, are, compared with those of the historical horses from Wünnenberg-Fürstenberg, and Lage-Müssen (SPRINGHORN 1980 and 1991) throughout longer and wider (4$10 \%) ; M_{2}$ and $M_{3}$ are wider but mainly shorter. This relative shortness certainly is depending on the claiming by $\mathrm{M}_{4}$. The total chewing surface of the tooth row $\mathrm{P}_{2}-\mathrm{M}_{3}$ measures $31.38 \mathrm{~cm}^{2}$, that of $\mathrm{P}_{2-}$ $\mathrm{M}_{4} 34.65 \mathrm{~cm}^{2}$. The largest specimen of the historical horses documents a chewing surface of close to $31 \mathrm{~cm}^{2}$. Measurements of the limb bones, modified after DRIESCH \& BOESNECK (1974), yield results which show certain differences regarding height of withers. The data of radius $(140 \mathrm{~cm})$ and tibia $(142 \mathrm{~cm})$ are approximately equal, but the metatarsal $(129.3 \mathrm{~cm})$ is significantly smaller. The corresponding classification of VITT (1952) assignes horses with height of withers between $136-144 \mathrm{~cm}$ to the category „middle shaped“ and those between $128-136 \mathrm{~cm}$ to „small shaped“. The discrepancy of about $13 \mathrm{~cm}$ and $11 \mathrm{~cm}$, respectively, is important. On the other hand Driesch \& Boesneck (1974: 333-34) documented two historical horse skeletons from the awarian funeral ground of Vienna-Liesing showing differences of $10.3 \mathrm{~cm}$ and $9.5 \mathrm{~cm}$. The authors communicated also that measurements of one specimen mostly fall into two categories of VITT. The ascertained heights of withers coincide completely with those of Przewalski Horse by VOLF (1972: 564): $120-146 \mathrm{~cm}$. Historical horses from the two archaeological sites in eastern Westfalia (SPRINGHORN 1980 and 1991) don't differ significantly in absolute size, but demonstrate the variability of the domestic successors of Equus przewalskii. In addition, dealing with Mesolithic and Neolithic horse bones, it is not possible to distinguish between the wild and domestic form (DöHle 1999: 151). There 
is also a coincidation in heights of withers (141 $-145.5 \mathrm{~cm}$ ) with the Late Pleistocene horse of Remagen near Bonn (NoBIs 1971: 47). The mean height of withers of Merowingian-Karolingian horses (6-7th and 9th century) from WünnenbergFürstenberg is $139 \mathrm{~cm}$, and falls into VITT's category "middle shaped" horses. The mean height of withers of medieval horses (10-11th and 13th century) from Lage-Müssen is $144 \mathrm{~cm}$ and fits just the upper limit of this category.

\section{Measurements in $\mathrm{mm}$ :}

Length of diastema Cinf. $-\mathrm{P}_{2}$ sin. $=59$

Height of ramus ascendens up to processus glenoidalis $=204$

Height of the ramus horizontalis below $\mathrm{P}_{4}=72, \mathrm{M}_{1}$ $=74.7, \mathrm{M}_{3}=88.2$, and $\mathrm{M}_{4}=99$

Length $\mathrm{P}_{2}-\mathrm{M}_{3} \sin .=164.3, \mathrm{P}_{2}-\mathrm{M}_{4}=181.4$

Left lower teeth: $\mathrm{I}_{3}(10 \times 14.2), \mathrm{C}(13.5 \times 11.6), \mathrm{P}_{2}$ (33.3x19), $\mathrm{P}_{3}(28.1 \times 20.3), \mathrm{P}_{4}(27.8 \times 21.8), \mathrm{M}_{1}$ (25.2x19.1), $\mathrm{M}_{2}(24.3 \times 18.2), \mathrm{M}_{3}(30.8 \times 17), \mathrm{M}_{4}$ (25.9x 18.2)

Upper teeth: $\mathrm{I}^{2} \sin .(12 \times 13.1), \mathrm{I}^{3} \sin (11.6 \times 14.3)$, $\mathrm{P}^{2}$ dext. $(35.8 \times 21)$

Radius dext.: length $=326.8$, lateral lg. $=322.5$, proximal width $=73.9$, distal $\mathrm{wd} .=71.1$, smallest circumference $=111.3$

Tibia sin.: lg. 348.2, lt. lg. 332.6, prox. $w d .=93.2$, dist. wd. $=76.6$, sm. ccf. $=121.2$

Metatarsale tertium sin.: lg. $=245.9$, lt. $\lg .=242 . .6$, prox. wd. $=44.1$,

dist. wd. $=43.5$, sm. ccf. $=83$

Phalanx I prox.: lg. $=85$, prox. $\mathrm{wd}$. $=56.4$, wd. of prox. facies articularis $=47.3, \mathrm{sm}$. $\mathrm{ccf}$. 34.2 , dist . wd. $=45.8$, dist. wd. fac. artc. $=42.2$

\section{Acknowledgements}

I thank Peter Vollmer M.A. for the incitement of the presented paper; he was working about stone age collections of the Lippisches Landesmuseum, and came across the wild horse material from Kempen. My secretary, Sonja Helming, who was helpful in managing the computer version of my manuscript. Photos were taken by my colleague JÜRGEN IHLE.

I am also indebted to Mrs. Annette Hibbeler for compiling and drawing the map.

\section{References}

Alberdi, M.-T. (1989): A review of Old World Hipparionine horses. - In: PROTHERO, D. R. \& SCHOCH, R. M., [Eds.]: The Evolution of Perissodactyls: 234-261, 6 figs.; New York, Oxford (Clarendon Press and Oxford Univ. Press).

Aaris-Sørensen, K. (1992): Deglaciation chronology and re-immigration of large mammals. A South Scandinavian example from late Weichselian-early Flandrian. - Courier Forsch.-Inst. Senckenberg, 153: 143-149, 4 figs., 2 tabs., Frankfurt a.M.

BröMLER, K. (1954): Die Altersbestimmung beim Kleinpferd aufgrund der Zahnentwicklung und -abnutzung. - Diss. Univ. München: 47 ps., div. figs. and plts; Munich.

Clutton-Brock, J. \& Burleigh, R. (1991): The mandible of a Mesolithic Horse from Seamer Carr Yorkshire, England. - In: MEAdow, R. H. \& UerPMANN, H.-P. [Eds.]: Equids in the Ancient World, 2: 238-241, 3 figs., 1 tab.; Wiesbaden (Ludwig Reichert).

Corbet, G.B. (1978): The mammals of the Palaearctic Region. A Taxonomic review. - 314 ps., 104 maps; Brit. Mus. (Natur. Hist.), London, Ithaca (Cornell Univ. Press).

Döhle, H.-J. (1999): Pferdenachweise aus dem Mesolithikum und Neolithikum in Deutschland. - In: BECKER, C. [Ed.]: Historia Animalium ex Ossibus, Internationale Archäologie, 8: Studia honoraria: 149159, 2 figs., 1 tab.; Rahden/Westf. (Marie Leidorf).

Driesch, A. v. d., \& Boessneck, J. (1974): Kritische Anmerkungen zur Widerristhöhenberechnung aus Längenmaßen vor- und frühgeschichtlicher Tierknochen. - Säugetierkdl. Mitt., 22: 325-348, 2 figs. 11 tabs.; Munich.

Forsten, A. (1993): Size decrease in Late Pleistocene Holocene cabbaloid horses (genus Equus), intra- or interspecific Evolution? - Quaternary International, 19: 71-76; Oxford.

Kiesewalter, I. (1888): Skelettmessungen an Pferden als Beitrag zu einer theoretischen Grundlage der Beurteilungslehre des Pferdes. - Diss. Univ. Leipzig: 38 ps., 3 shts., 2 tabs.; Leipzig.

Koenigswald, W. v., Walders, M. \& Sander, M. (1995): Jungpleistozäne Tierfährten aus der Emscher-Niederterrasse von Bottrop-Welheim. - Münchener Geowiss. Abh., A 27: 5-50, 52 figs., 37 tabs.; Munich.

Kurten, B. (1968): Pleistocene mammals of Europe. The World Naturalist: 317 ps., 111 figs., 15 tabs.; London (Weidenfeld \& Nicolson).

Luley, H. (1990): Ortsteil Kempen, Stadt Horn-Bad Meinberg, Kreis Lippe. - In: Westf. Mus. f. Archäol. u. Amt f. Bodendenkmalpflege Münster i.W. [Ed.] 1991, Neujahrsgruß: 24-25; Münster i.W. 
Nehring, A. (1884): Fossile Pferde aus deutschen Diluvial-Ablagerungen und ihre Beziehungen $\mathrm{zu}$ den lebenden Pferden. - Landwirtschaftl. Jb., 13: 81158, Dresden, Leipzig (Arnold).

Nickel, R., Schummer, A. \& Seiferle, E. (1977): Lehrbuch der Anatomie der Haustiere: 539 ps., 517 figs.; Berlin, Hamburg (Paul Parey).

Nilson, T.(1983): The Pleistocene. Geology and Life in the Quaternary Ice Age. - 651ps., 237 figs.; Stuttgart (Ferdinand Enke).

Nobis, G. (1971): Vom Wildpferd zum Hauspferd. Studien zur Phylogenie pleistozäner Equiden Eurasiens und das Domestikationsproblem unserer Hauspferde. - Fundamenta, B 6: 96 ps., 7 figs., 6 plts., 58 diagrs., 126 tabs.; Cologne, Vienna (Böhlau).

Poliakov, I. S. (1881): Sistematiceskij obzor polevok, vodjascichsja v cibri. - Imperatorskoj Akademii Nauk; Zapiski. Otcet po Fiziko-Matematiceskomu i Istoriko-Filologiceskomu Otdélenijam, Suppl. Vol. 39 (2): 92 ps., 9 figs., 1 plt., 11 tabs.; Moscow.

Siegrried, P. (1983): Fossilien Westfalens. Eiszeitliche Säugetiere. - Eine Osteologie pleistozäner Großsäuger. - Münster. Forsch. Geol. Paläont., 60: 163 ps., 40 plts.; Verein d. Geolog. Stud. Münster [Ed.], Münster i.W.

Springhorn, R. (1980): Pferdereste eines wikingerzeitlichen Siedlungsplatzes bei Müssen (Lippe). - Z Tierzüchtung u. Züchtungsbiologie, 97: 116-126, 5 figs., 4 tabs.; Hamburg, Berlin.
- (1991): Die Pferde des frühmittelalterlichen Körpergräberfriedhofes von Wünnenberg-Fürstenberg. - Bodenaltertümer Westfalens, 25: 133-160; Münster i.W.

STARCK, D. (1995): Lehrbuch der speziellen Zoologie, Vol. II: Wirbeltiere, Part 5/2 Säugetiere. - 1241 ps., 564 figs.; Jena, Stuttgart, New York (Gustav Fischer).

Street, M. \& BaAles, M. (1999): Pleistocene/Holocene changes in the Rhineland fauna in a northwest European context. - In: Bennecke, N. [Ed.]: The Holocene History of the European Vertebrate Fauna. Modern Aspects of Research. Archäologie in Eurasien, 6: 9-38, 3 figs., 14 tabs.; Rahden/Westf. (Marie Leidorf).

VITT, V. O. (1952): Die Pferde der Kurgane von Pasyryk (russisch). - Sovjetskaja Arch., 16: 163-205, 23 figs., 9 tabs.; Moscow.

Volf, J. (1972): Wildpferde. - In: Grzimek, B. [Ed.]: Grzimeks Tierleben 12, Einhufer und Pferdeverwandte: 564-575, 8 figs.; Zurich (Kindler).

Wiegank, F. (1983): Beitrag zur Chronostratigraphie und Entwicklung im jüngeren Känozoikum von Europa auf geochronologischer und magnetostratigraphischer Grundlage. - In: HeinRICH, W.-D., [Ed.]: Wirbeltier-Evolution und Faunenwandel im Känozoikum. - Schriftenreihe für Geologische Wissenschaften, 19/20: 355-364, Berlin (Akademie). 